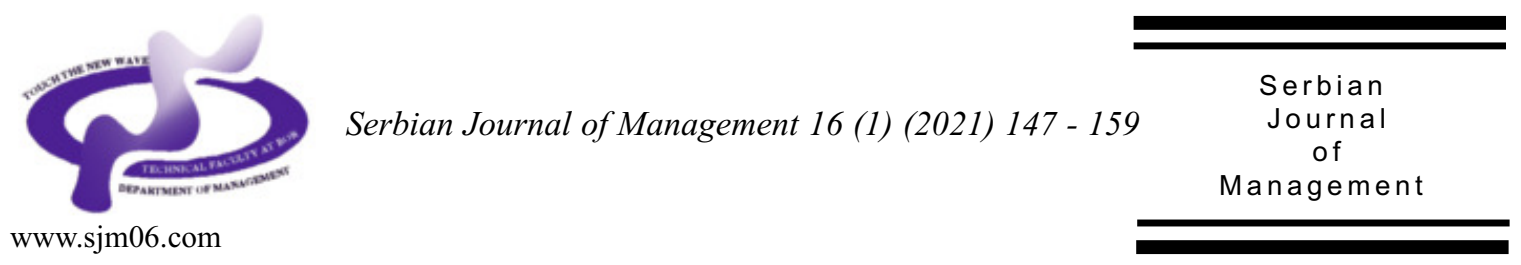

\title{
THE DIGITAL TRANSFORMATION PROGRAM MANAGEMENT IN MEDIUM-SIZED BUSINESSES: A NETWORK APPROACH
}

\author{
Valery Anshin a and Alla Bobyleva ${ }^{b^{*}}$

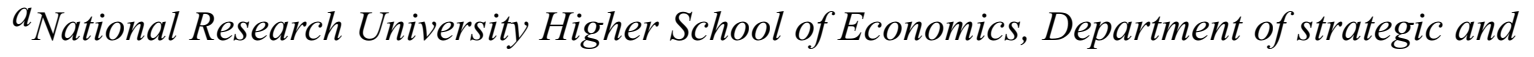 \\ international management, Microdistrict 3rd, 18-91, g. Moskovskiy, Moscow, Russia.

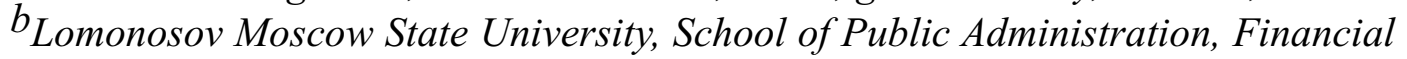 \\ Management Department, Kutuzovsky prospect 33-176, Moscow, Russia.
}

(Received 29 December 2020; accepted 01 March 2021)

\begin{abstract}
The article deals with the process management's issues of digital transformation in companies. The emphasis is made on the consideration of program's projects as interrelated components with the features of emergency system, not as a weakly interconnected complex (linear set) of projects. Authors propose the organizational model of transformation's program management and the new approach to prioritizing projects based on the use of network analysis. The suggested method allows to evaluate the role of the project in the transformation program and its impact on the other projects, as well as its impact on the planned benefits of the program. It also allows to distribute resources between projects and to assess the risks of the program as a whole. The article focuses on the differences of medium-sized companies' management methods, on the one hand, from companies in small business, and on the other hand, from large companies. The application of the method was tested at a medium-sized poultry farm. The analysis of projects of the real program was made, the network model of the program was built, and the probability of projects' and the program at all success was estimated. The evaluation of the program indicators allowed the authors to make conclusions about priorities of separate projects. The proposed approach can be used in various companies, regardless of industry affiliation.
\end{abstract}

Keywords: digital transformation, program management, network approach, medium-sized business

\section{INTRODUCTION}

Issues of digital transformation are usually considered with regard to certain industries. The primary areas of digital transformation are high-tech industries associated with the production and distribution of software as well as the fuel and energy sector, oil and gas sector, military-industrial complex, the banking

*Corresponding author: bobyleva@spa.msu.ru

DOI: $10.5937 /$ sjm16-30088 
sector. The difference of our approach is that the object of the research is not large business or IT companies, but medium-sized businesses. Digital transformation is not an area of activity for them, but a driving force for development.

The logic of considering the digital transformation at medium-sized businesses separately is validated by the difference between their management systems and management at large companies. In mediumsized businesses digitalization is in its infancy: manual mode and reactive measures prevail in management models. Especially it is necessary to emphasize the following management features in medium-sized businesses:

- top management or owner of the company often has to solve both strategic and current issues and has no chance to focus on the main problems;

- there are no regulations for accepting new projects, projects are not considered as elements of a program. Decisions are made by the owner, and they are based not so much on calculations and systemic vision, as on intuition and experience;

- internal processes are focused on coordination with the owner or top management, not on interaction between employees. This can lead to an increase in time to perform tasks;

- a number of employees has to combine various and sometimes not corresponding functions in areas in which they are not proficient;

- owners and employees often rely on intuition, common sense, past experience rather than on professionalism. Such circumstances lead to low adaptability of companies.

Thus, as a rule, managers in mediumsized companies do not use modern opportunities. Nevertheless, medium-sized enterprises are often referred to as the backbone of the European economy, providing a potential source for economic growth. In this regard, the management of digital transformation in medium-sized businesses is a very urgent problem. Its solution will structure and formalize strategic decision-making, will ensure the consideration of the company's projects as interrelated components of a program. This will help to evaluate the role of each project taking into account its impact on other projects and the program as a whole.

\section{LITERATURE REVIEW}

A considerable amount of scientific publications have been devoted to the issues of the medium-sized business (MB) development. In particular, the works of BosBrouwers (2010), Klewitz and Hansen (2014), Koe et al. (2015) are dedicated to the influence of $\mathrm{MB}$ on the sustainable growth. The systemic empirical investigations of $\mathrm{MB}$ development are presented in the works of Bobyleva et al. (2011), World Bank (2015), Bykovskaya et al. (2018). As a whole, there is a significant amount of papers studying certain aspects of MB development and factors influencing its growth but there are not so many comprehensive works researching the matters of internal strengthening of sustainability, the opportunities of SME self-development.

Regarding our research area, change management is considered by Franklin (2011) and in Practice Guide of Project Management Institute (2013). The problems of program management are deeply studied by Thiry (2015). Also these issues are presented in such practical guides as "The 
standard for portfolio management" (2017), "The standard for program management" (2017). More specific issues, for example, the prioritization of projects, were raised by Cooper et al. (2002), Anshin and Ilyina (2013). Risk management was examined by Ghasemi et al. (2018), and Sanchez et al. (2008). Interconnection of projects was analyzed by Neumeier et al., (2018) and Bilgin et al. (2017).

The article by Reis et al. (2018) differs from previous literature as it strictly focuses on the concept of digital transformation. The paper delivers a general overview of the literature but it is limited by comparison of various definitions of digital transformation. Empirical studies of digital transformation are made by Gimpel \& Röglinger (2015). Such research areas as digital business enterprise architecture are raised in the works of Chen et al. (2016), McDonald and Rowsell-Jones (2012). Attempts to integrate "digital" into the DNA of the business models were made by Hess et al. (2016), Kane et al. (2015), and Matt et al. (2015).

However, the prevalence of illustrative case studies in these works is a clear indication of the lack of maturity of methodology. Moreover, most of the existing publications do not consider medium businesses separately and do not reveal any special digital transformation program management for them. Thus, the insufficient use of the potential of medium-sized businesses in many countries, the lack of comprehensive scholarly works on mediumsized businesses management, the low level of methodological support for digital transformation programs based on the system approach have led to the choice of the topic and the range of issues that require priority consideration.

\section{POTENTIALITY OF DIGITAL TRANSFORMATION IN MEDIUM- SIZED BUSINESS}

Digital transformation is one of the main directions of transformation in the modern economy. It is often understood in the narrow sense, as the implementation of automation without changing the processes themselves. But the digital transformation goes beyond merely digitizing resources and results in value and revenues being created from digital assets.

We consider the digital transformation as a fundamental change in the company's strategy and its implementation. It affects the main areas of management: relations with the external environment; internal business processes; resource base, including material resources, human capital and corporate culture, finance. The substance of digital transformation in a broad sense is a change in the logic and content of processes. This means the company's transition to project (program) management based on clear goalsetting, systematic review and evaluation of processes and projects, big data analysis and the implementation of digital technologies.

Such an understanding of digital transformation provides the following possibilities:

- establishment of regulations for accepting new projects and considering their combination into programs. This will increase the systematicity of management and help to focus on results;

- development of employee interaction algorithms, simplification of their interaction, reduction of business processes duration, increased transparency of management;

- implementation of predictive analytics technologies; 
- processing a large volume of systematized data, which allows to optimize business processes by timely identifying problem areas and growth drivers;

- management of businesses in different regions based on remote monitoring system. It gives the possibility of growth by means of mergers and acquisitions.

A separate task of digital transformation is the implementation of the appropriate corporate culture in the company. This may be the most difficult change for mediumsized companies, since in many cases it is not professional skills that are valued, but informal relationships, including family ones. Therefore, it is easier to build a business in a digital style "from scratch" than to rebuild an existing one. However, the proposed organizational model for a managing of a transformational program may be useful both for a newly created company and for a company that is restructuring its activities.

\section{ORGANIZATIONAL MODEL OF DIGITAL TRANSFORMATION PROGRAM MANAGEMENT}

Managing a digital transformation program is a part of a company's change management system. If we consider the modern classification of changes, then the digital transformation can be attributed to changes of the second or the third order, depending on its scale (Anshin, 2016).

Changes of these orders should always be a part of the company's strategy. The authors propose strategic organizational model for managing such changes (Figure 1).

The model can be divided into three components: the general strategy, the digital transformation strategy and the system of the digital transformation program management.

The general strategy includes perspective, goals, the chain "strategy - portfolio of projects - transformation programs". Digital transformation strategy is the subsystem of general company's strategy. Its specific elements are a part of the general strategy. At the same time, the digital transformation program management is a subsystem of the digital strategy.

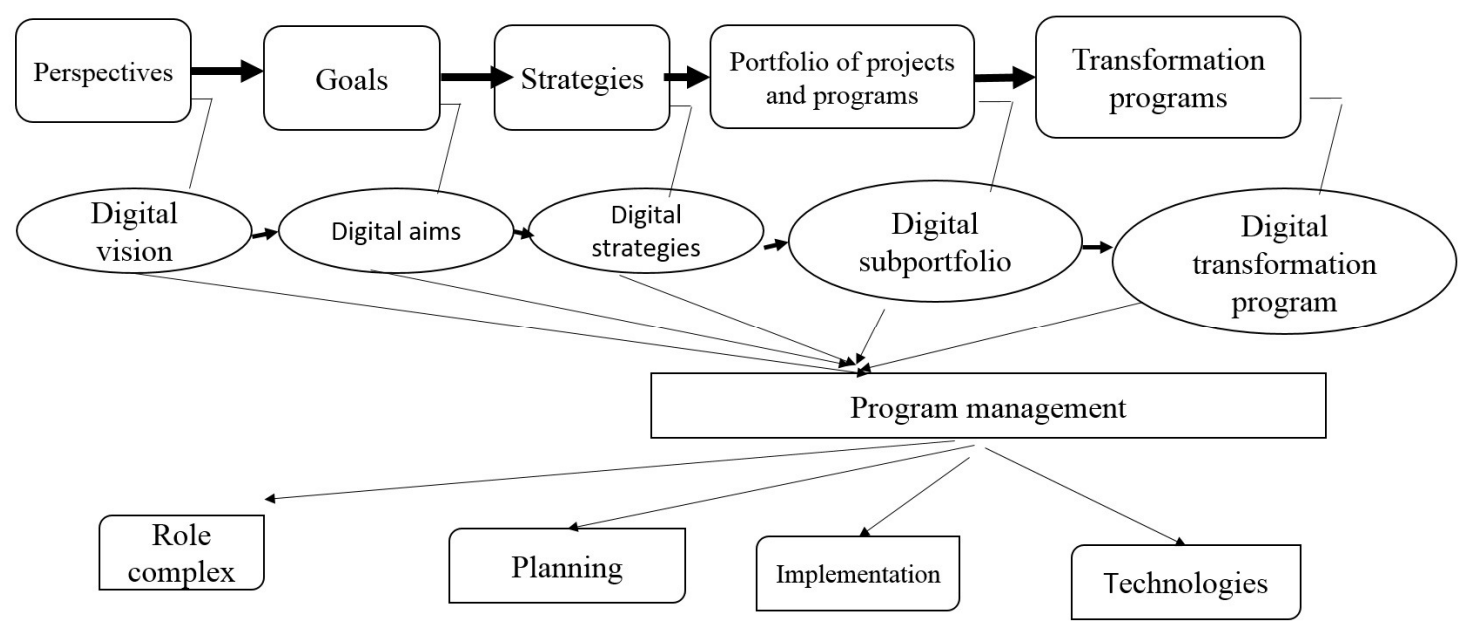

Figure1. Strategic organizational model for managing Transformation Program 
The research shows that the development and organization of large-scale changes are more successful when using a program approach (Franklin, 2011; Thiry, 2015; The standard for program management, 2017). The program approach provides means of managing results, timescales and resources of changes. A special feature of the digital transformation program is its more complex design in comparison with traditional organizational change programs. This type of program includes a block that contains information and technology projects: quantum solutions, artificial intellect, wireless communication, robotics, sensorics, virtual and augmented reality technologies, etc. The development of such projects is a difficult task for medium-sized companies, requiring large investments and highly qualified specialists.

The next feature of the digital transformation program, as well as all highorder change programs, is the high degree of projects' interdependence in the program. In some types of simple programs a weak interdependence of projects is possible. In other words, the program is an "umbrella of projects" (Figure 2).

The digital transformation program is characterized by network interdependence of projects (Figure 3 ).

\subsection{Managing the risk of a transformational program}

The main risk of the program is not achieving its goals. In many cases, goals are complex and are defined by several indicators. Achieving the goals of the program depends on many factors and the main of them is the successful development of program's projects.

Assessment of the success of projects and programs involves:

- establishing of interconnections between projects and their mutual influence;

- evaluation of each project's probability of success and failure;

- evaluation of the conditional probabilities of project success depending on the success of the "parent" projects. Parent projects are projects that affect other program projects dependent on them;

- development of a map of benefits and probabilities of receiving final benefits, depending on the probability of success of "feeding" benefits. "Feeding" benefit is the benefit from a child project, which is taken into account with a certain weight $(W j)$ when calculating the degree of achievement of the program goal (Figure 4).

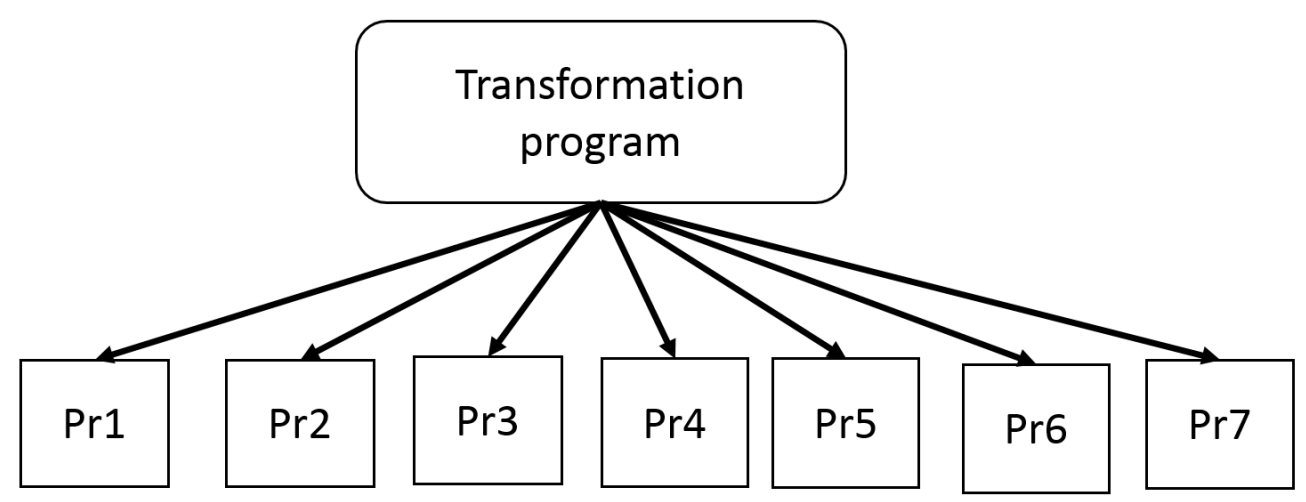

Figure 2. The program as an umbrella of independent projects 


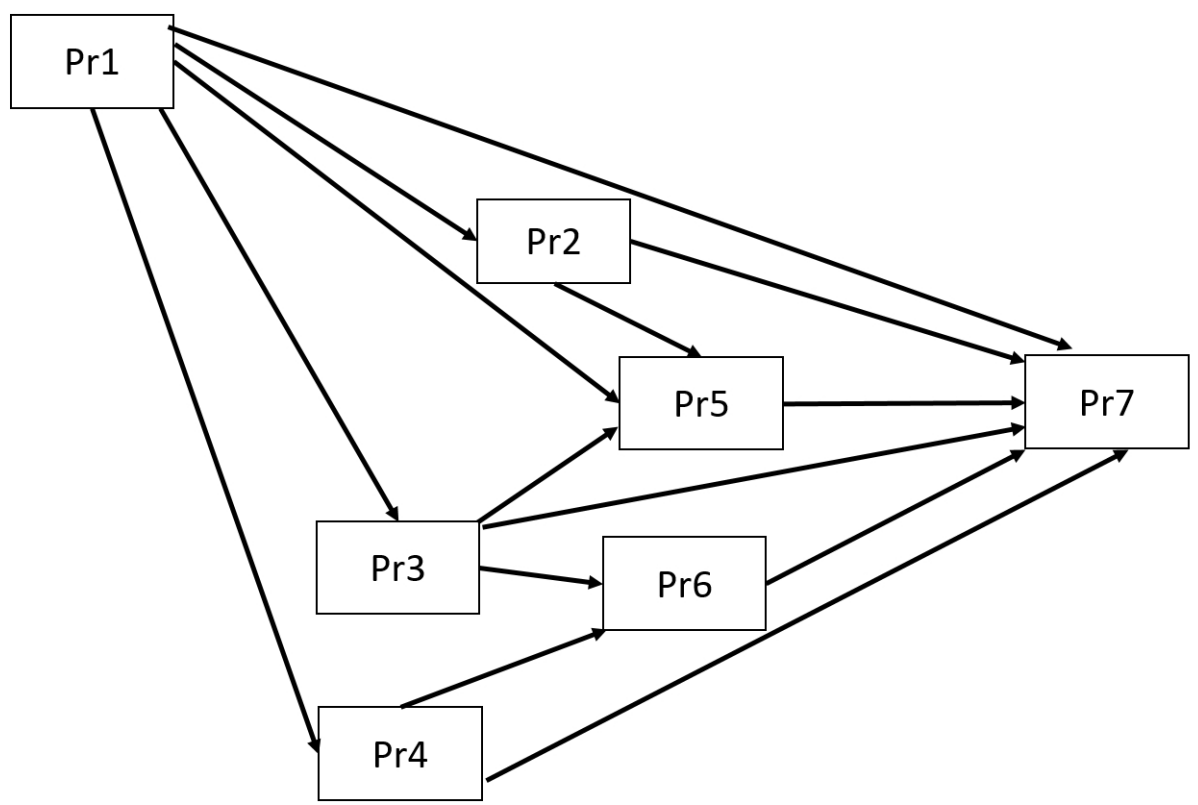

Figure 3. Network interdependence of projects in digital transformation program

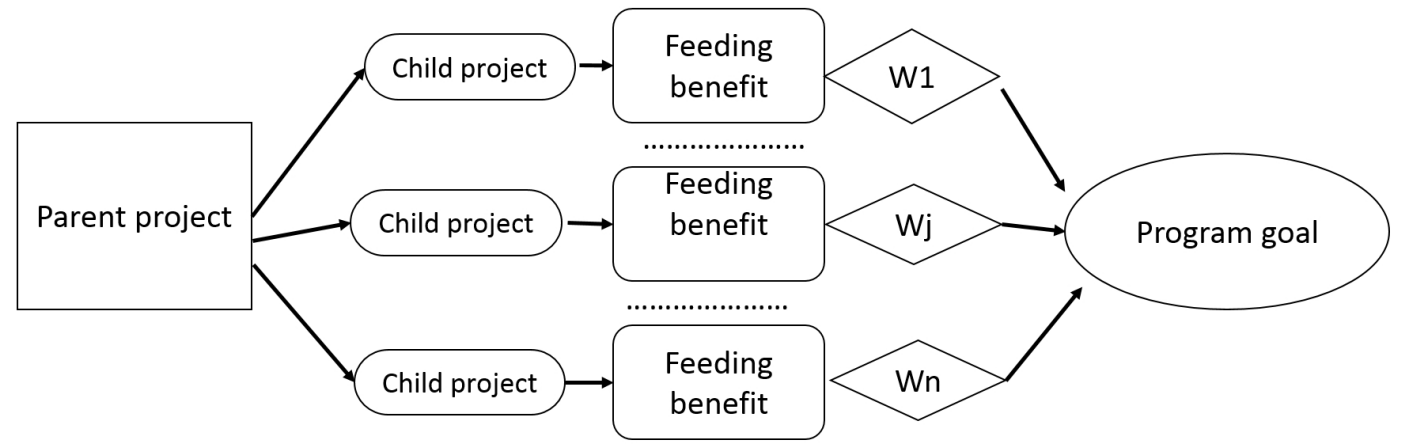

Figure 4. The scheme of projects and feeding benefits' participation in achieving the goal of the program

\subsection{The probability of achieving program goal}

The risk of a program can be measured according to the probability of achieving its goal. A low probability, and therefore risk, occurs when the probability of receiving feeding benefits is low.

Let us consider the bunch "parent project - child project - program benefit". The result of the child project development is the creation of a feeding benefit, which contributes to the program goal achievement. The probability of success in creating a program benefit depends on the success of the parent projects and associated child projects.

Let us denote the success of projects by $S$, the failure by $F$,

$Z_{i}$-parent project $i$

$C_{j}{ }^{i}$ - child project $j$, associated with parent project $i$, 
$P\left(Z_{i}, S\right)$ - probability of success of the parent project $i$,

$P\left(Z_{i}, F\right)$ - probability of failure of the parent project,

$P\left(C_{j}{ }^{i}, S / Z_{i}, S\right)$ - conditional probability of success of child project $j$ in case of success of parent project $i$,

$P\left(C_{j}{ }_{j}, S / Z_{i}, F\right)$ - conditional probability of success of child project $j$ in case of failure of parent project $i$.

The probability of success of the $j$-th child project associated with the development of the $i$-th project can be determined as (1):

$P\left(C_{j}^{i}, S\right)=P\left(Z_{i}, S\right) \cdot P\left(C_{j}^{i}, S / Z_{i}, S\right)+$

$P\left(Z_{i}, F\right) \cdot P\left(C_{j}^{i}, S / Z_{i}, F\right)$

In a simplified version, let us assume that project $j$ creates one benefit, which, along with the benefits of other projects, contributes to the achievement of goal $k$. In this case, the probability of achieving the $k$ goal of the program in case of creation feeding benefits $j$ can be determined as (2):

$P\left(G_{k}\right)=\sum_{j}^{n} W_{j}^{k} \cdot P\left(B_{j}^{k}\right)$

where $W_{j}^{k}$ is the weight of the $j$ benefit in the goal $k$,

$B_{j}{ }^{k}$ - is feeding benefit, created by project $j$, contributing to the achievement of the goal $k$,

$P\left(B_{j}{ }^{k}\right)$ - is the probability of success in creating the $j$ benefit for the $k$ goal.
Then a scale of success probability in achieving the goal can be developed. It will allow to assess the acceptable risk of the program.

Every company creates a scale based on its characteristics, including the level of risk tolerance. The authors propose such configuration of a scale:

P1 - P2 - comfortable level of probability of a program goals achievement,

P3 - P4 - acceptable level of probability of a program goals achievement,

below $\mathrm{P}_{\min }$ - critical level of probability of a program goals achievement,

P1, P2, P3, P4, $P_{\min }$ - levels of probability of program goals achievement.

If the level of risk of the goal achievement is close to critical, it is necessary to go through the chain to feeding benefits and to the corresponding parent and child projects. The implementation of risk reduction measures should increase the probability of success of these projects.

\subsection{Prioritization of program projects}

There are various approaches to prioritizing projects (Cooper et al., 2002; Anshin \& Ilyina, 2013; The standard for portfolio management, 2017). In many cases, they are based on a comparison of individual project indicators. A higher priority get better performing projects. However, the interconnection of projects, their role in the program and the impact on other projects are not taken into account in these methods. For example, a project may not have high financial indicators, but it's nonfulfillment will prevent other projects from being 
completed. Such a project can be called critical (Neumeier et al., 2018).Therefore, the evaluation system should be supplemented with an indicator showing the impact of the project on other projects in the program.

The authors propose a method for defining such a role. It is based on determining the place of projects in the project network of the program and its impact on other projects. This approach may be called transformation project prioritization based on network analysis TPPNA. It includes:

- development of the projects network and matrix of their interdependence (in network analysys it is called adjacency matrix);

- $\quad$ assessment of the projects network ranks based on the analysis of the adjacency matrix;

- allocation of resources between projects in accordance with relevant indicators and taking into account network ranks;

- development of a risk management system for specific projects in the light of network ranks of projects.

The network analysis methodology assumes the calculation of indicators that characterize network nodes (Neumeier et al., 2018). In our case, projects or benefits of the program are the nodes.

It is logical to assume that the project (benefit), which is associated with the largest number of other projects and affects their results, has a higher rank. Taking into consideration the network nature of transformation program, failure in the development of such a project can cause the failures of dependent projects.

To identify such significant projects, the authors propose to use an indicator that can be called the network rank of the projects impact. Its calculation can be made on the basis of a modified network analysis formula (3):

$$
R_{i}=2 \cdot \frac{\sum_{j}^{k} A_{i j}}{n(n-1)}
$$

where $R_{i}$ - project network rank, $n$ is a number of program projects, $A_{i j}$ is an indicator of interconnection of $i$ and $j$ projects (it can take the value 0 or 1 ).

The project with the highest $R_{i}$ gets the highest "partial priority". "Partial priority" means that it takes into account exclusively projects interconnections. Then all projects are ranked in descending order of network rank.

This indicator can be included in the general project scoring system. Also it has independent significance for the implementation of actions to increase the success of highly significant projects. In particular, additional resources may be allocated to such projects, incentives may be applied to project personnel, etc.

\section{THE MODEL OF THE POULTRY FARM DIGITAL TRANSFORMATION PROGRAM}

A poultry farm was chosen to develop a digital transformation program due to the high demand for such programs in this field. Both broiler and egg production are sectors of high socio-economic importance. A significant number of poultry farms are medium-sized businesses, and changing their management models will increase their productivity, improve the supply of food to the population. During crisis digital 
technology can play an unprecedented role for business recovery (Anshin \& Bobyleva, 2021). What was once a "nice to have" could become a "crucial to have".

The goal of the program is to create and implement a digital set of projects (Figure 3), with a built-in new accounting and planning system that ensures companies' value growth.

The program is supposed to include the following projects:

- The system concept of creating a smart poultry farm (Pr1). For example, it may combine farm's own parent herd, feed production, broiler production and processing, packing house, waste processing into an integrated system.

- Internet of Things (Pr2). It may be a project of using apps on gadgets to scan code from a broiler package or egg box and get information about the conditions and place of production. The project should help to promote production and increase farm's competitiveness.

- Artificial intelligence (Pr3). For example, the separation of meat from bones requires individual settings for each carcass due to differences in their shape and size.

- New managerial accounting and planning system in the context of digitalization (Pr4). It includes the development of schemes and forms for information exchange, new design of divisions' accounting and reporting, consolidation information for senior management.

- Robotics (Pr5). It could be the cleaning and disinfection of poultry houses, turning and aeration of the decking, etc.

- $\quad$ Sensorics (Pr6). For example, sensors can be used to determine the permissible concentration of ammonia, regulate and control the climate (temperature, ventilation), lighting in a poultry house.

- Digital organizational, production and technological complex of the company (Pr7). It involves the automation of the production process: remote computer control of feeding, water supply, weight gain control and poultry damage.

The relationship of the projects is presented in Table 1.

The creation of a digital organizational, production and technological complex of the company (Pr7) has the greatest impact on other projects of the program. But the success of this project depends on the success of other projects $(\operatorname{Pr} 1, \operatorname{Pr} 2, \operatorname{Pr} 3, \operatorname{Pr} 4$, Pr5, Pr6) to a large extent. The next most influential project is the creation of the smart poultry farm (Pr1). This project is related to project 7 . It can be explained by the high impact of the smart factory concept on the complex configuration. And vice versa, the

Table1. Project Interconnection Matrix (Adjacency Matrix)

\begin{tabular}{lccccccccc}
\hline Project & Pr1 & Pr2 & Pr3 & Pr4 & Pr5 & Pr6 & Pr7 & Total & $\begin{array}{l}\text { Network rank of } \\
\text { project impact }\end{array}$ \\
\hline Pr1 & 0 & 1 & 1 & 1 & 1 & 0 & 1 & 5 & 0.238 \\
Pr2 & 1 & 0 & 0 & 0 & 1 & 0 & 1 & 3 & 0.143 \\
Pr3 & 1 & 0 & 0 & 0 & 1 & 1 & 1 & 4 & 0.190 \\
Pr4 & 1 & 0 & 0 & 0 & 0 & 1 & 1 & 3 & 0.143 \\
Pr5 & 1 & 1 & 1 & 0 & 0 & 0 & 1 & 4 & 0.190 \\
Pr6 & 0 & 0 & 1 & 1 & 0 & 0 & 1 & 3 & 0.143 \\
Pr7 & 1 & 1 & 1 & 1 & 1 & 1 & 0 & 6 & 0.286 \\
\hline
\end{tabular}


structure and organization of the complex has the opposite effect on the concept. As follows from the table, individual technological projects are connected to a lesser extent.

The overall criterion for the success of the transformation program should be the generation of a synergetic effect from the projects included in the program.

\section{CONCLUSION}

Medium-sized companies exist in different industries. In some cases, they have passed the way from a small company to a medium business company. Such companies have experience of successful development, a certain maturity of business management processes.

Some medium-sized companies set the goal of further development and transition to the category of large companies. At such companies, prerequisites and conditions should be created for using advanced management methods, including program and project management.

One of the current directions of development is digitalization. Many medium-sized companies have the necessity and possibilities to introduce or increase the level of using digital technologies.

It is important to consider that business digitalization requires an interconnected set of high-order changes. Moreover, in case of significant digitalization, a transformation of the company is required. For its successful implementation, it is necessary to consider the transformation strategy as the part of the company's general strategy and develop an organizational model of digitalization.

The proposed model allows to implement a systematic approach to transformation management by developing a program as a subsystem of company's strategic management. The complex and multi-project nature of the digital transformation program makes it appropriate to present it as a network of interconnected projects. Among these projects, we can identify projects that affect other projects in the network and determine the success of the program as a whole.

It is proposed to introduce the concept of "feeding benefits" into scientific circulation to increase the level of manageability of achieving the program goal. "Feeding benefit" is a result of a project that directly affect the program goal.

It is important to determine the probability of achieving the program goal at the stages of planning and monitoring the program. The probability is determined by the probability of success in creating feeding benefits, taking into account their contribution to the achievement of this goal. If the probability of achieving the goal is low, it is recommended to develop solutions to increase the probability of success of critical projects along the chain of project relationships (from "right to left"). Project ranking is suggested by considering them as a network and calculating the project's network rank indicator. This indicator should be used in the process of identifying critical projects of the transformation program.

The application of the recommended methodology is illustrated by the example of a digital transformation program for a poultry farm.

Digitalization processes are very intense in the poultry industry. Implementation of the program management methodology, the network presentation of the interconnection and ranking of projects will significantly increase managerial maturity and success in 
digitization.

The proposed approach was tested at one of the poultry farms in the Moscow region. Network construction and calculations made it possible to determine the network ranks of projects, to rank projects and identify the most critical ones that have the greatest impact on other projects and on the success of the program as a whole.

At the same time, we should notice that despite the big possibilities of the proposed methodology, it has limitations. Little attention is paid to the control of the external environment: the assessment of the competitive environment, customer segments, commercial conditions, etc.; the concept of sustainable development is not integrated in the model; the indicators for step-by-step monitoring of the interim results of the program and the overall synergy effect have not been established. Our further research will focus on the development of these aspects of the digital transformation program management.

\section{References}

Anshin, V. (2016). A systematic approach to managing transformational programs in a company (in Russian). Scientific Research and Development Russian Journal of Project Management, 5 (2), 3-20.

Anshin, V., \& Bobyleva, A. (2021). Digital transformation programs as crisis management mechanism (on the example of broiler production), AIC: Economics, Management, 2, 33-40. (In Russian).

Anshin, V., \& Ilyina, O. (2013). Project Management. Fundamental course (in Russian). Higher School of Economics. Moscow, Russia.

Bilgin, G., Eken, G., Ozyurt, B., Dikmen,
I., Birgonul, M.T., \& Ozorhon, B. (2017). Handling project dependencies in portfolio management. Procedia Computer Science, 121, 356-363.

Bobyleva A.Z., Sazhina M.A., Bobylev S.N., Peganova O.M., Kashirova A.V., Zhavoronkova E.N., Tsarenko A.S., \& Lvova O.A. (2011). Management in conditions of instability of the financial and economic system: strategy and instruments (in Russian). Izdatelstvo Moskovskogo universiteta, Moscow, Russian Federation.

Bos-Brouwers, H.E.J. (2010). Corporate sustainability and innovation in SMEs: evidence of themes and activities in practice. Business Strategy and the Environment, 19 (7), 417-435.

Bykovskaya, Y.V., Ivanov, L.N., \&Safohina, E.A. (2018). Small and mediumsized businesses in modern Russia: conditions, problems and directions of development (in Russian). Vestnik Evrazyiskoy nauki, 10 (5), 1-16.

Chen, Y.K., Jaw, Y., \& Wu, B. (2016). Effect of digital transformation on organizational performance of SMEs: evidence from the Taiwanese textile industry's web portal. Internet research: Electronic networking applications and policy, 26 (1), 186-212.

Cooper, R.G., Edgett, S.J., \& Kleinschmidt, E.J. (2002). Portfolio management for new products (2nd edition). Basic Books. USA.

Franklin, M. (2011). Managing business transformation. A practical guide. IT Governance Publishing. Cambridgeshire, United Kingdom.

Ghasemi, F., Sari, M.H.M., Yousefi, V., Falsafi, R., \& Tamošaitienè, J. (2018). Project Portfolio Risk Identification and Analysis, Considering Project Risk Interactions and Using Bayesian Networks. 
УПРАВЉАЊЕ ПРОГРАМОМ ДИГИТАЛНЕ ТРАНСФОРМАЦИЈЕ У ПРЕДУЗЕһИМА СРЕДЫЕ ВЕЛИЧИНЕ: МРЕЖНИ ПРИСТУП

\author{
Valery Anshin, Alla Bobyleva
}

\title{
Извод
}

Чланак се бави питањима управљања процесима дигиталне трансформације у компанијама. Акценат је стављен на разматрање програмских пројеката као међусобно повезаних компоненти са карактеристикама система за ванредне ситуације, а не као слабо међусобно повезаних сложених (линеарних скупова) пројеката. Аутори предлажу организациони модел управљања програмом трансформације и нови приступ одређивању приоритета пројеката заснован на употреби мрежне анализе. Предложени метод омогућава процену улоге пројекта у програму трансформације и његовог утицаја на остале пројекте, као и његовог утицаја на планиране користи програма. Такође омогућава дистрибуцију ресурса између пројеката и процену ризика програма у целини. Чланак се фокусира на разлике у методама управљања средњих предузећа, с једне стране, од компанија у малом предузећу, а са друге стране, од великих компанија. Примена методе тестирана је на фарми живине, као предузећу средње величине. Направљена је анализа пројеката стварног програма, изграђен је мрежни модел програма и процењена је вероватноћа успеха пројеката и програма уопште. Процена програмских показатеља омогућила је ауторима да донесу закључке о приоритетима засебних пројеката. Предложени приступ може се користити у разним компанијама, без обзира на припадност индустрији.

Кључне речи: дигитална трансформација, управљање програмима, мрежни приступ, предузећа средње величине

Sustainability, 10 (5), 1609.

Gimpel, H., \& Röglinger, M. (2015). Digital Transformation: Changes and Chances-Insights Based on an Empirical Study. Fraunhofer Institute for Applied Information Technology FIT. Sankt Augustin, Germany.

Hess, T., Matt, C., Benlian, A., \& Wiesböck, F. (2016). Options for formulating a digital transformation strategy. MIS Quarterly Executive, 15 (2), 123-139.

Kane, G., Palmer, D., Phillips, A.N., Kiron, D., \& Buckley, N. (2015). Strategy, not Technology, Drives Digital Transformation. MIT Sloan Management Review and Deloitte University Press, 14 (125).
Klewitz, J., \& Hansen, E.G. (2014). Sustainability-oriented innovation of SMEs: a systematic review. Journal of Cleaner Production, 65, 57-75.

Koe, W., Omar, R., Sa'ari, J.R. (2015). Factors Influencing Propensity to Sustainable Entrepreneurship of SMEs in Malaysia. Procedia - Social and Behavioral Sciences, 172, 570 -577.

Managing Change in Organizations: A Practice Guide (2013). Project Management Institute. Pennsylvania, USA.

Matt, C., Hess, T., \& Benlian, A. (2015). Digital transformation strategies. Business and Information Systems Engineering, 57 (5), 339-343.

McDonald, M., \& Rowsell-Jones, A. 
(2012). The Digital Edge: Exploiting Information \& Technology for Business Advantage. Gartner Inc. Stamford, Connecticut, USA.

Neumeier, A., Radszuwill, S., \& Zare Garizy, T. (2018). Modeling project criticality in IT project portfolios. International Journal of Project Management, 36 (6), 833- 844.

Reis, J., Amorim, M., Melão, N., Matos, P. (2018). Digital Transformation: A Literature Review and Guidelines for Future Research. In Rocha, Á., Adeli, H., Reis, L., Costanzo, S. (eds). Trends and Advances in Information Systems and Technologies. WorldCIST'18, 745, Springer, Cham. 411421.

Sanchez, H., Robert, B., \& Pellerin, R. (2008). A Project Portfolio Risk-Opportunity Identification Framework. Project Management Journal, 39 (3), 97-109.

The standard for portfolio management. Fourth edition (2017). Project Management Institute. Pennsylvania, USA.

The standard for program management. Fourth Edition (2017). Project Management Institute. Pennsylvania, USA.

The World Bank. (2015). Small and Medium Enterprises (SMEs) Finance. Retrieved from https://www.worldbank.org/en/topic/smefina nce.

Thiry, M. (2015). Program Management. Gower. Farnham, Surrey, England; Burlington, VT, USA. 